\title{
Potential of marine sponge-derived fungi in the aquaculture system
}

\author{
MUHAMMAD SYAIFUDIEN BAHRY ${ }^{1,2}$, OCKY KARNA RADJASA ${ }^{3,4}$, AGUS TRIANTO ${ }^{1,2 \vee}$ \\ ${ }^{1}$ Department Marine Science, Faculty of Fisheries and Marine Science, Universitas Diponegoro. Jl. Prof. Soedarto, SH, Tembalang, Semarang 50275, \\ Central Java, Indonesia. Tel./fax.: +62-24-7474698, `email: agustrianto.undip@ gmail.com. \\ ${ }^{2}$ Marine Natural Product Laboratory, Centre for Research and Services, Universitas Diponegoro. Jl. Prof. Soedharto, S.H. Tembalang, Semarang 50275, \\ Central Java, Indonesia \\ ${ }^{3}$ Tropical Marine Biodiversity Laboratory, Faculty of Fisheries and Marine Science, Universitas Diponegoro. Jl. Prof. Soedarto, SH, Tembalang, \\ Semarang 50275, Central Java, Indonesia \\ ${ }^{4}$ Research Center for Oceanography, Indonesian Institute of Sciences. Jl. Pasir Putih I, Ancol Timur, North Jakarta 11048, Jakarta, Indonesia
}

Manuscript received: 4 May 2021. Revision accepted: 24 June 2021.

\begin{abstract}
Bahry MS, Radjasa OK, Trianto A. 2021. Potential of marine sponge-derived fungi in the aquaculture system. Biodiversitas 22: 2883-2892. Organic waste from aquaculture is one of the triggers of disease outbreaks and a decrease in water quality that urgently needs to be resolved. Indonesia has a high diversity of sponges including their associated microorganisms that potential in the field of biotechnology. This study aimed to determine the enzymatic and anti-vibrio activity of fungi associated with marine sponges and identify potential fungi. The specimen of sponges was collected from Samalona Island, South Sulawesi, Indonesia. The enzymatic and anti-vibrio assay was conducted by using the plug method and the activity was determined by a clear zone around the fungal isolates. Fungal identification was carried out molecularly using universal primers ITS1 and ITS4 and phylogenetic tree analysis. The fungal isolates were screened for the extracellular enzyme activity (amylase, cellulase, protease) and anti-vibrio activity against Vibrio parahaemolyticus, $V$. harveyi, and $V$. vulnificus). A total of three fungal isolates have been isolated from the sponge Monanchora sp. Isolate SL 3 SP 3.3 had potential enzymatic activities with Enzymatic Indeks (EI) $3.95 \pm 0.17$ on amylase, $3.75 \pm 0.36$ on cellulase, $5.38 \pm 0.30$ on protease. The highest anti-vibrio activity was obtained against $V$. harveyi with an inhibition zone diameter of $4.82 \pm 0.37$ $\mathrm{mm}$. The results of fungal identification showed that isolate SL3SP3.3 had a sequence length of 638 bp and was closely related to Trichoderma reesei a.k.a Hypocrea jecorina with a similarity value of $99.69 \%$.
\end{abstract}

Keywords: Amylase, anti-vibrio, associated fungi, cellulase, protease, sponge

\section{INTRODUCTION}

Aquaculture is an important aspect of the security of Indonesia's food resources. The development of marine aquaculture is increasing along with the high demand of the international market. Fish and shrimp are the leading commodities in the aquaculture sector and Indonesia is one of the largest exporters of fishery products to Japan, America, and the European Union (Wati 2018). However, the disease outbreaks in marine aquaculture, including vibriosis, are serious problems in the Indonesian mariculture industry. The Food and Agriculture Organization of the United Nations (FAO 2018) reports that these infections cause international losses of nearly US $\$ 3$ billion per year.

The biggest problem in aquaculture is that $40-60 \%$ of the total production cost is allocated to feed, while the efficiency of feed absorption is not optimal (Olmos et al 2011). This is due to aquaculture fish are carnivores that do not easily digest vegetable protein, while the carbohydrates in the feed are only absorbed by $20 \%$ because they are not the main energy source (Kurniawan et al. 2019). Excess nutrition cause problems because it requires more energy and prolongs the digestion period to hydrolyze protein, fat, and carbohydrate bonds (Rachmawati et al. 2020). On the other hand, improper pond management causes poor water quality that leads to vibriosis disease which can cause mass mortality in cultured shrimp and environmental pollution
(Kusumaningrum and Zainuri 2015). The marine sponge is a marine organism that has high bioactivity. The genus Monanchora is rich in sources of novel secondary metabolites exhibiting diverse biological activities. The major group of metabolites of the genus Monanchora is guanidine-derived alkaloids (Dyshlovoy et al. 2016), which were isolated from different Monanchora species (Wang et al. 2013), and steroid (Wang et al. 2013). Guanidinederived alkaloids (Dyshlovoy et al. 2016), showing the wide scope of biological activities, e.i. anti-parasitic (Santos et al. 2015), anticancer and antibacterial (Gogineni et al. 2020), antiviral (Hua et al. 2007), antifungal (Arevabini et al. 2014), and cytotoxic (El-Demerdash et al. 2016). The potential sources of natural products in Indonesia so far have not been well explored. The development of new drugs derived from marine biota is currently a concern of researchers because of its excellent potential and the unique structure of their secondary metabolites. Bioactive compounds derived from the sea can be an alternative in the development of new antibacterial drugs and biotechnological sources (Radjasa et al. 2009, 2011).

Suryanarayanan (2012) stated that marine bioactive substances are produced by sponges and produced by microbes living in or around the hosts called holobiont, including marine fungi. Fungi are categorized as "marine fungi" if they are obligate and sporulate independently in seawater (Proksch et al. 2003). The microbes associated 
with sponges provide excellent bioprospects, such as antiviral, broad-spectrum antibacterial, antifungal, and antiprotozoal. Broad-spectrum antibacterial means that act against Grampositive and Gram-negative pathogenic bacteria such as Staphylococcus spp., Streptococcus spp., Bacillus spp., Clostridium spp., Escherichia spp., and Pseudomonas spp. (Indraningrat et al. 2016). Some marine fungi Trichoderma sp. and Penicillium sp. isolated from sponges have activity against bacteria that cause vibriosis (Sibero et al. 2018). Fungi also produce hydrolytic and/or oxidative enzymes to play an important role in the ecological environment as decomposers (Panno et al. 2013) and its industrial application for biotechnological enzyme viz. alginate lyase, amylase, cellulase, chitinase, glucosidase, inulinase, keratinase, ligninase, lipase, nuclease, agarase, phytase, protease, and xylanase, cellulase, amylase, lipase, and pectinase.

\section{MATERIALS AND METHODS}

\section{Sample collection}

The sponge samples were collected from Samalona Island, Makassar, South Sulawesi, Indonesia: $5^{\circ}$ 07'
37,410" SL $119^{\circ} 20^{\prime} 24,010$ " EL (Figure 1) at 5-10 m depth. The purposive random sampling method was used for the sampling method (Etikan et al. 2016). Sponge samples were documented under and above the water using underwater labels for identification purposes. Samples were transferred into the sterile ziplock and stored in the coolbox to avoid contamination.

\section{Isolation and purification of the fungi}

Fungal isolation was performed by tapping method according to Trianto et al. (2020). Sponge samples were cleaned using sterile marine water to remove microbial contaminant on the surface of the sponge then cut into approximately $1 \times 1 \mathrm{~cm}$ and tapped into the sterile PDA plate (Merck, Germany) with three repetitions. After 7 days of incubation, the emerging fungi were purified into the new sterile PDA plate using the plug method and incubated for 3-5 days at room temperature until the fungus grew (Wittriansyah et al. 2016). PDA was supplemented with chloramphenicol $(2 \%)$ to avoid bacterial contamination.

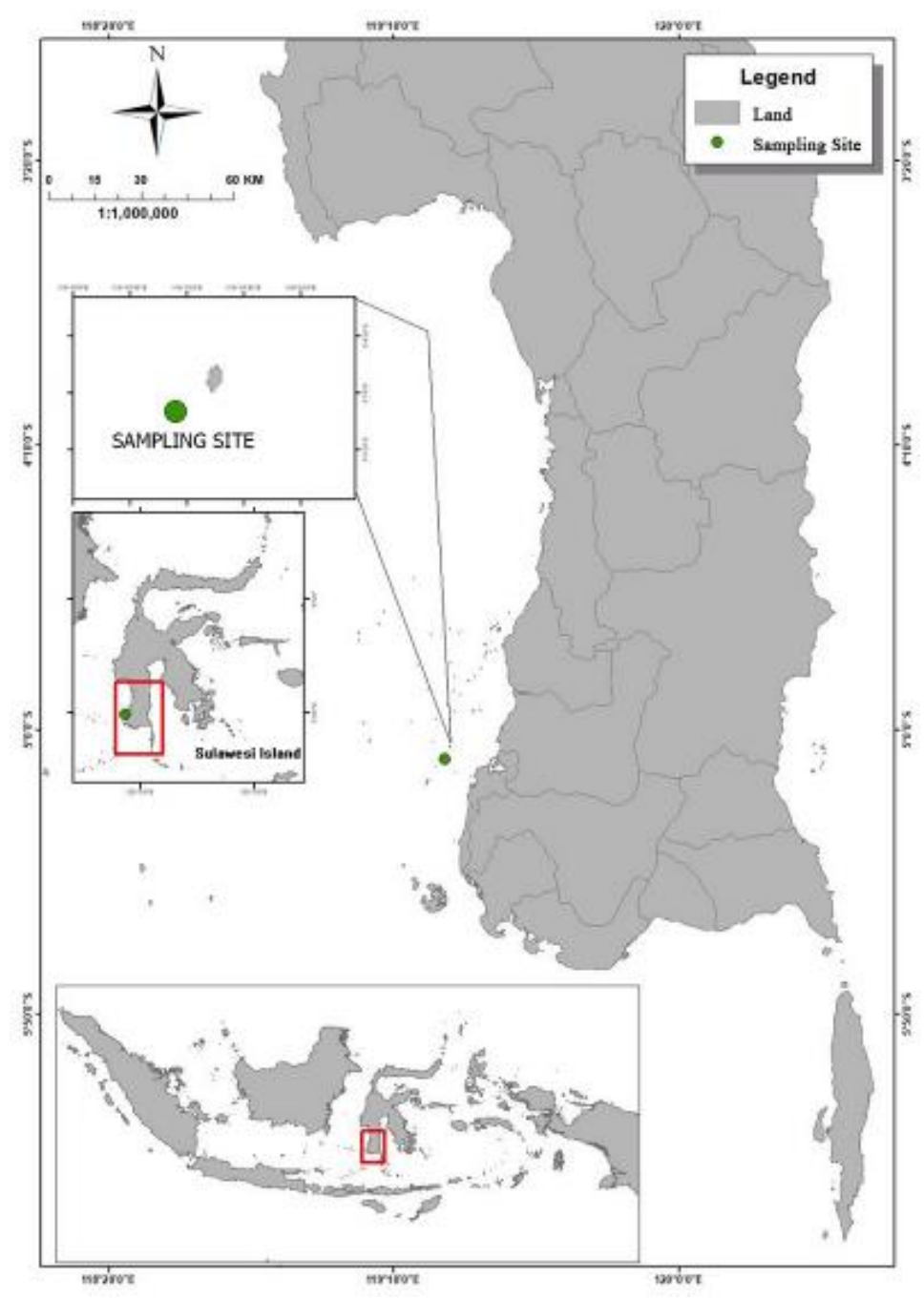

Figure 1. Sampling site of Monanchora sp. in Samalona Island, South Sulawesi, Indonesia (507’37.410” SL 119²0’24.010” EL) 


\section{The anti-vibrio screening}

The anti-vibrio assay was conducted by the agar plug method (Sabdaningsih et al. 2017; Trianto et al. 2020). A total of 3 vibriosis causative (Vibrio harveyi, $V$. parahaemolyticus, and V. vulnificus), collection of Tropical Marine Biotechnology Undip Laboratory, Semarang were used for anti-vibrio screening. The Vibrio bacteria were grown on nutrient broth to a concentration of 0.5 McFarland and then inoculate on a trypticase soy agar (TSA) plate (Merck, Germany) using sterile cotton swabs (ONEMED, Indonesia). Seven days old of the fungal disk was plugged on TSA and incubated at $27^{\circ} \mathrm{C}$ for $24 \mathrm{~h}$ (Sibero et al. 2018; Cristianawati et al. 2019).

\section{The enzymatic activity assay}

Cellulase-producing fungi were screened on a $\mathrm{CMC}$ agar plate. A circle shape fungi $(8 \mathrm{~mm})$ from PDA medium was inoculated on a CMC agar plate (CMC 1\%, Agar 2\%) and incubated for 7 days at $30^{\circ} \mathrm{C}$ (Coronado-Ruiz et al. 2018). Amylase activity was carried out using a soluble starch agar plate ( $2 \%$ soluble starch, and $2 \%$ agar). The fungal disk was placed on the soluble starch agar plate and incubated for 7 days (Khokhar et al. 2012; Ogbonna et al. 2014). Gram's iodine stain $(2.0 \mathrm{~g} \mathrm{KI}$ and $1.0 \mathrm{~g}$ iodine in $300 \mathrm{~mL}$ distilled water) was used as a hydrolysis indicator. On the last day of the incubation, CMC plates and soluble agar were flooded with a $10 \mathrm{~mL}$ Gram's iodine stain for 10 min (Colonia and Junior 2014). The amylase activity was determined by the starch hydrolysis, which can be seen in the presence of hydrolysis zone around the fungal plate colony (Lübeck and Lübeck 2018). The skimmed milk agar (SMA) plate was used to determine the extracellular protease production (Sharma et al. 2015). The SMA plate was made by mixing the suspension of agar and marine water $(2,5 \%)$ then sterilized at $121^{\circ} \mathrm{C}$ for $15 \mathrm{~min}$. The mixture was poured into a solution of $10 \%(\mathrm{w} / \mathrm{v})$ of skimmed milk powder (Merck, Germany) that heated in a water bath at $50^{\circ} \mathrm{C}$. The screening was done by inoculating the fungal disk onto the SMA plate and incubated at $27^{\circ} \mathrm{C}$ for $96 \mathrm{~h}$. The hydrolysis zone around the colony indicates protease activity due to the casein hydrolysis process (Kamath et al. 2010; Maitig et al. 2018). The enzymatic activity was determined by clear zone formation around the fungal disk (Lusi et al. 2017). The enzymatic index (EI) was measured as a semi-quantitative estimate of the enzyme activities, according to the formula below (Coronado-Ruiz et al. 2018; Maitig et al. 2018).

$$
E I=\frac{\text { Diameter of clear zone }}{\text { Diameter of colony }}
$$

\section{Extraction and evaporation}

After 7-day of incubation, the medium and mycelia of fungi were extracted using ethyl acetate as a solvent by maceration (Handayani et al. 2016) for 72 hours with solvent replacement every 24 hours (Sedjati et al. 2020). The filtrate was evaporated using a rotary vacuum evaporator (Eyela ${ }^{\circledR} \mathrm{N} 101$, Tokyo, Japan) at $35^{\circ} \mathrm{C}$ to get the concentrated extract (Bahry et al. 2017).

\section{The anti-vibrio assay}

The bioassay for anti-vibrio was carried out using the agar disk diffusion method (Sabdaningsih et al. 2019). Extracts that have been made with a dilution series (500, $250,100 \mu \mathrm{g} / \mathrm{disk})$ are diffused on a paper disk $(6 \mathrm{~mm}$, Oxoid. ltd) The disk was placed on the surface of the plate that had been inoculated with vibriosis vector and incubated for $2 \times 24$ hours. Observations were carried out every 24 hours. Antibiotic chloramphenicol $30 \mu \mathrm{g}$ was used as a positive control and solvent (DMSO 10\%) was used as a negative control. (Dermawan et al. 2019).

\section{Identification for potential sponge}

Identification of sponges was performed by observing the shape of the spicules under a microscope (Sabdaningsih et al. 2019). The distribution and taxonomy of sponges were confirmed by using the online World Porifera Database, while the book Systema Porifera: A Guide to the Classification of Sponges was used as a reference for the identification of morphology and spicules. (Hooper and Van Soest 2002; De Voogd et al. 2008; van Soest et al. 2012).

\section{Molecular identification for potential fungal}

The DNA extraction of potential fungus was carried by DNA MiniPrep (ZYMO Research, USA). DNA amplification was performed using a polymerase chain reaction (PCR) thermal cycler (Biorad $\mathrm{T} 100^{\mathrm{TM}}$, USA) and internal transcribed spacer (ITS) as the region of fungal DNA (Alvarez-Navarrete et al. 2015). The reaction was performed using a total volume of $25 \mu \mathrm{L}$ PCR mix which contain $12.5 \mu \mathrm{L}$ of GoTaq Green Master Mix (Promega, USA), $1 \mu \mathrm{L}$ of ITS1 (5'- TCC GTA GGT GAA CCT GCG G-3') as forward-primer, $1 \mu \mathrm{L}$ of ITS4 (5'-TCC TCC GCT TAT TGA TAT GC-3') as a reverse-primer, $9.5 \mu \mathrm{L}$ of $\mathrm{ddH} 2 \mathrm{O}$ and $1 \mu \mathrm{L}$ of DNA template. The PCR setting was: denaturation at $95^{\circ} \mathrm{C}$ for $1 \mathrm{~min} ; 34$ cycles of denaturation at $95{ }^{\circ} \mathrm{C}$ for $3 \mathrm{~min}$, annealing at $56.1^{\circ} \mathrm{C}$ for $1 \mathrm{~min}$, extension at $72{ }^{\circ} \mathrm{C}$ for $1 \mathrm{~min}$; final extension at $72{ }^{\circ} \mathrm{C}$ for $7 \mathrm{~min}$ and cooling at $4^{\circ} \mathrm{C}$ until the reaction over (Trianto et al. 2021). The quality of the PCR products was assessed using electrophoresis at $1 \%$ agarose. The visualized PCR results were analyzed at 1st Base Laboratories, Malaysia through PT. Genetics Science Jakarta for sequencing. DNA sequences were analyzed for homology using the Basic Local Alignment Search (BLAS) (www.ncbi.nlm.nih.gov). Phylogenetic trees were reconstructed and analyzed using MEGA 7.0 software while the neighbor-joining method with 1000 bootstrap replication was chosen for statistical analysis. (Kumar et al. 2016; Trianto et al. 2021).

\section{RESULTS AND DISCUSSION}

The Spermonde archipelago of Makassar water was chosen as the sampling site because of the biodiversity of the marine invertebrate especially the marine sponge (De Voogd et al. 2006). Samalona Island is the middle inner zone of the Spermonde archipelago which is dominated by 
a healthy coral reef ecosystem (Muller et al. 2014; Yusuf et al. 2021). The sample of SL.3-SP3 is an encrusting sponge that covers a dead gorgonian.

The photograph of sponge SL.3-SP3 and the spicule were presented in Figure 2. The SL.3-SP3 sponge has four different megasleres i.e.; style (Figure 2C. D), oxea (Figure 2E), diaene (Figure 2F), sphaerancora (Figure 2G), sigma c (Figure 2H). Based on its megascleres, the sample SL.3SP3 sponge is identified as Monanchora sp. (Van Soest et al. 1996) reported that Monanchora sp. contains all spicules including styles and sigma.

The characteristics of Monanchora sp. are Crambeidae without pseudoastrose, encrusting to a lobate or ramose life form with smooth or extended into corrugated or spined projections surface (Hooper and Van Soest 2002). This sponge is commonly found around the world viz; Brazil (Santos et al. 2015), Thailand (Kaewkrajay et al. 2021), Jamaica (Hua et al. 2007). Monanchora sp. was also found in Indonesia viz; Seribu island (Hadi 2011), North Sulawesi (Calcinai et al. 2017).

The bioactive compounds in Monanchora sp. are mostly found as alkaloids, i.e. batzelladine isolated from the Caribbean sponge Monanchora sp. has activity against human cancer cell lines, protozoa, HIV-1, and AIDS opportunistic infectious pathogens (Hua et al. 2007). Monanchocidin from the Monachora pulchra has anticancer activity against cervical cancer and monocytic leukemia in human and mouse epidermal cell line in mouse (Kiran et al. 2018). Guanidine, an alkaloid that has cytotoxic properties and prevents EGF-Induced Neoplastic was isolated from Monachora pulchra (Dyshlovoy et al. 2016). Gogineni et al. (2020) reported that Monanchocidin A has the terrific activity against pathogenic microorganisms including bacteria (Staphylococcus aureus ATCC 29213, Methicillin-resistant S. aureus (MRSA) ATCC 33591, Escherichia coli ATCC 35218, Pseudomonas aeruginosa ATCC 27853, and Mycobacterium intracellulare ATCC 23068), and fungi (Candida albicans ATCC 90028, Candida glabrata ATCC 90030, Candida krusei ATCC 6258, Aspergillus fumigatus ATCC 204305, and Cryptococcus neoformans ATCC 90113). It is proven that activity is bigger than the antibiotic control (Ciprofloxacin and amphotericin B).

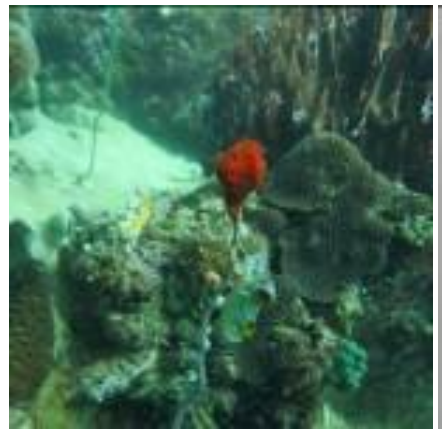

A

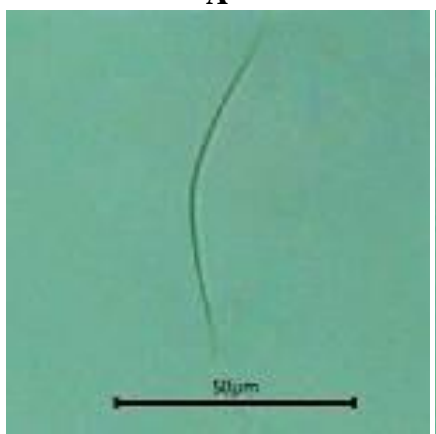

$\mathbf{E}$

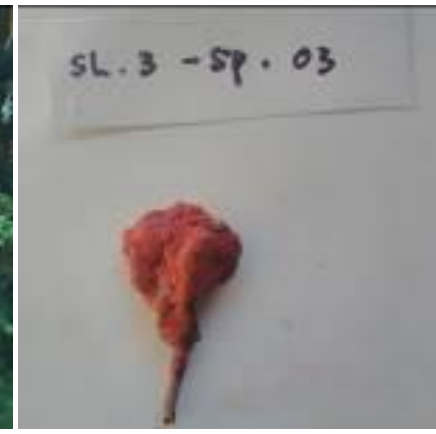

B

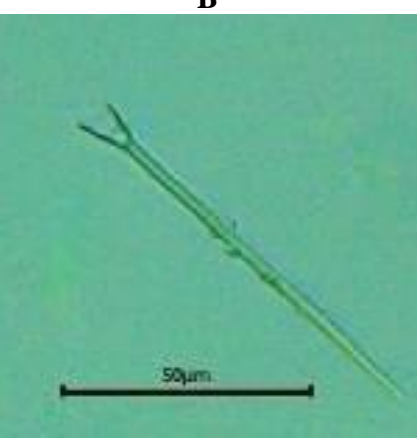

$\mathbf{F}$

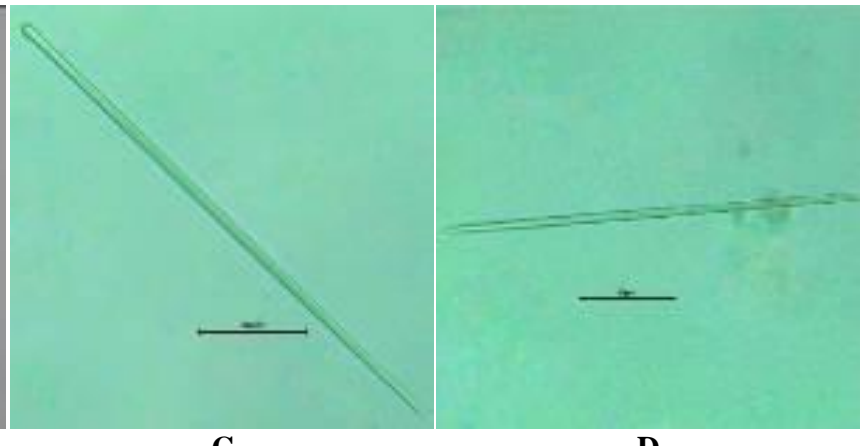

C

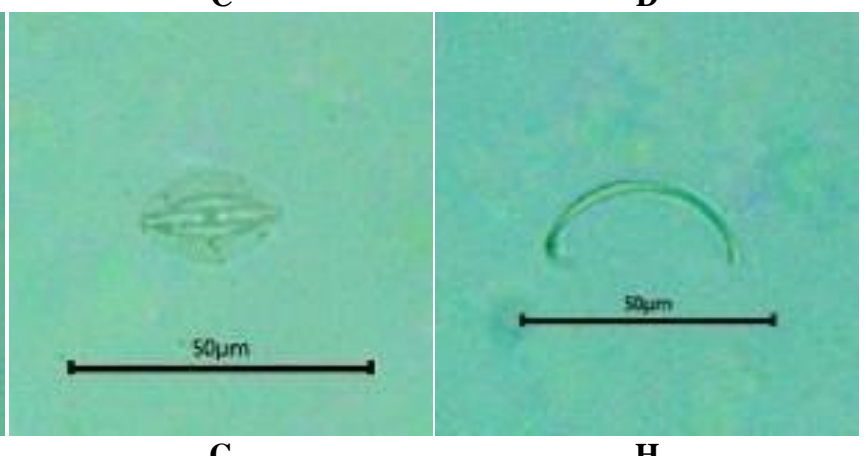

G

$\mathbf{H}$

Figure 2. The picture of the SL 3 SP 3 sponge and its spicules. A. The under the water picture, B. The above the water picture, C. Style spicule, D. Style spicule, E. Oxea spicule, F. Diaene spicule, G. Sphaerancora spiclue, H. Sigma spicule

Table 1. The morphology of 3 fungal isolates from sponge SL.3-SP.03

\begin{tabular}{lllll}
\hline \multicolumn{1}{c}{ Isolate code } & \multicolumn{1}{c}{ Colour } & \multicolumn{1}{c}{ Filament } & Spora & Note \\
\hline SL 3 SP 3.1 & Green & Nonfilamentous & Spore & - \\
SL 3 SP 3.2 & Grey & Nonfilamentous & Spore & - \\
SL 3 SP 3.3 & White-green & Filamentous & Non-sporous & Produce yellow pigment \\
\hline
\end{tabular}




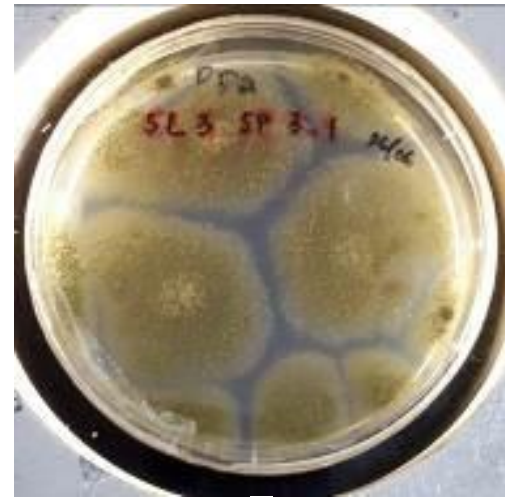

A

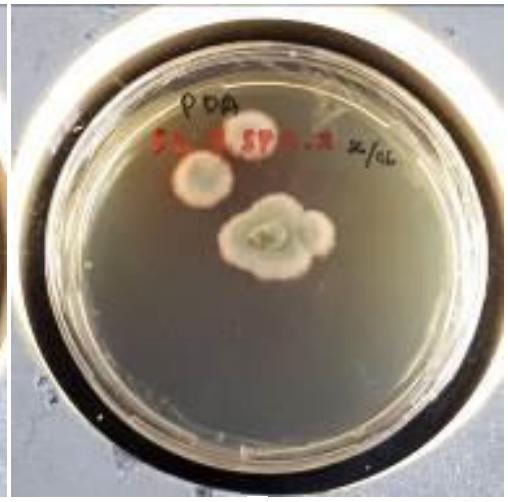

B

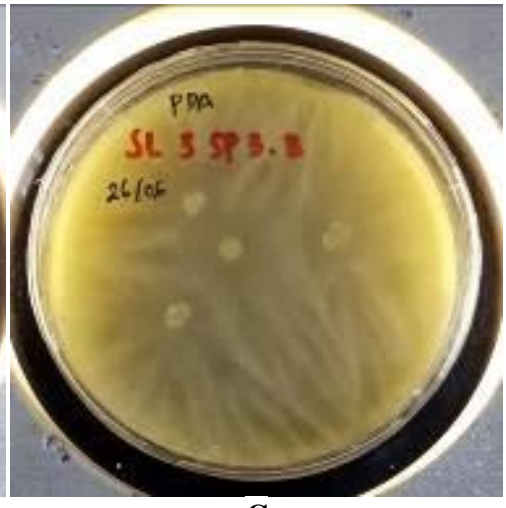

C

Figure 3. The morphology of fungal colony of: A. SL.3-SP.03.1, B. SL.3-SP.03.2, C. SL.3-SP.03.3

A total of 3 fungal isolates were obtained from the Monanchora sponge. The small number of fungi isolated from Monanchora sp. was due to the Monanchora sponges were categorized as low microbial abundance (LMA) sponges (Gloeckner et al. 2014). A previous study by Kaewkrajay et al. 2021 showed that there was no culturable microbial found from 6 samples of M. unguiculata sponge taken from the Gulf of Thailand, South China Sea. All three fungal isolates have different characteristics, as shown in Figure 3, and their morphological characteristics were presented in Table 1. The isolate SL 3 SP 3.3 has a unique characteristic by producing yellow pigment which was shown in the color change of the medium.

The results showed that the SL3 SP3.2 isolate had neither enzymatic activity nor antibacterial against three Vibrio species. Isolate SL 3 SP 3.3 had antibacterial activity against three Vibrio species and three enzymatic activities, while the SL 3 SP 3.1 isolate only inhibits the growth of $V$. vulnificus (Table 2). Antibacterial activity is categorized as bacteriostatic and bactericidal. According to Silva et al. (2011) bactericidal activity was indicated by the absence the bacterial colony growth or reduction of $99.9 \%$ inoculum bacterial and bacteriostatic activity was indicated as maintenance of the original inoculum or a reduction of less than $99.9 \%$ the inoculum bacterial.

The enzymatic activity of fungal isolates is shown in Figure 4.A (amylase), 4.B (cellulase), and 4.C. (protease). A clear area or hydrolysis zone around the fungal colony indicated hydrolysis of the test media due to the activity of the enzyme (amylase, cellulase, protease) (Rengasamy and Thangaprakasam 2018). Cellulase-producing microorganisms were screened on agar plates enriched with CMC as a carbon source and using Gram iodine as an indicator. Qualitative determination is based on the presence of cellulose hydrolysis which is characterized by a clear zone around the fungal colony. This is due to the interaction of iodine with cellulose and its degraded components so that the integral biopolymer retains Gram iodine dye (Coronado-Ruiz et al. 2018). For protease production, the nitrogen source of natural protease production was determined by using different sources (peptone, tryptone, casein, and yeast extract) (Ahmed 2018).

\section{Molecular identification of SL3 SP3.3 fungal isolate}

The molecular identification process was initiated by extracting DNA of potential isolates SL 3 SP 3.3 using a DNA extractor. The results of electrophoresis visualization are used to determine the success of DNA extraction as indicated by the appearance of bands (white lines) from the PCR product samples (Figure 5) Figure 5. shows that DNA samples of fungal isolate SL 3 SP 3.3 have been successfully extracted with a length of \pm 500 base pairs. This stage determines the feasibility of the sample for sequencing.

BLAST analysis on NCBI was used to determine the level of similarity of the isolates compared to the isolates in GenBank data. The sample was analyzed based on the similarity of the nucleotide acid composition with a certain basepair length. Table 3 shows the result of homology analysis of the isolate sequence of SL 3 SP 3.3 which has a sequence length of $638 \mathrm{bp}$ and has a $99.69 \%$ similarity with the Trichoderma reesei $\mathrm{RHa}$ strain under the accession number KM246746.1. Primers covered the sequence length of the fungal isolate ITS 1 and ITS 4 with amplification ranged 750bp and 500bp (Yan et al. 2011). ITS primer is a primer that matched $99 \%$ of ascomycete and basidiomycete taxa (species, subspecies, or varieties) based on public sequence databases named in silico analysis (Toju et al. 2012).

The phylogenetic tree with the maximum likelihood method is shown in Figure 6 and was made based on the Internal Transcribed Spacer (ITS) region, with 1000 bootstrap replications. The number of each node presents bootstrap values from Neighbor-Joining (NJ). The sample has a branch trust value of $1000(100 \%)$ with the Trichoderma reesei acc number KM246746.1. which is shown by its position to form the same clade.

T. reesei has specific hyphae characteristics and has blue color with methylene blue dye under the microscope. The culture medium affects the morphological shape of 
fungus. Carpa et al. (2018) reported that T. reesei formed "bundle" granules which were difficult to distinguish between off-cornched mycelia and growth hyphae and offcornched conidiophores with sporangial heads on solid media observed by SEM. T. reesei lengthens the hyphae and increased hyphal branching to increase interaction with the substrate thereby increasing the production of enzymes. T. reesei is commonly found in asexual form (teleomorph Hypocrea jecorina) (Zhang et al. 2019).

Bioassay was performed to evaluate the activity of SL 3 SP 3.3. (T. reesei) crude extract against three species of Vibrio (V. harveyi, V. vulnificus, $V$. parahaemolyticus) with the concentrations of 500, 250, $100 \mu \mathrm{g} / \mathrm{disk}$. The highest activity was obtained at a concentration of $500 \mu \mathrm{g} / \mathrm{disk}$ against $V$. harveiy with an inhibition zone of $4.82 \pm$ $0.37 \mathrm{~mm}$, while the diameter of the inhibitory zone of positive control was $19.50 \pm 1.66 \mathrm{~mm}$.

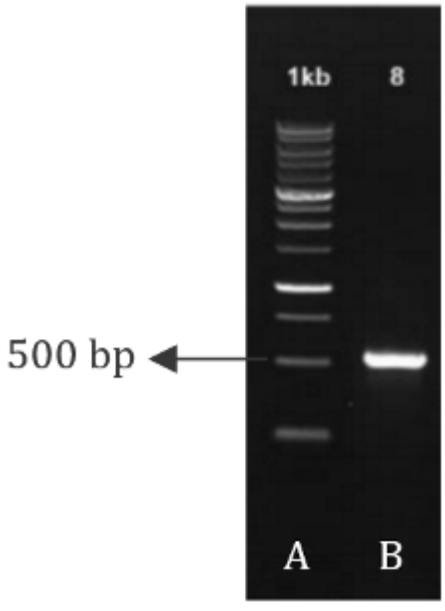

Figure 5. A. DNA ladder, B. DNA template of isolate SL 3 SP 3.3

Tabel 2. Screening of anti-vibrio activity and enzyme activity of fungi isolated from sponge SL.3 SP03

\begin{tabular}{cccccccc}
\hline \multirow{2}{*}{ Isolate Code } & \multicolumn{4}{c}{ Anti-vibrio activity } & \multicolumn{2}{c}{ Enzyme activity } \\
\cline { 2 - 7 } & & V. harveyi & V. vulnificus & V.parahaemolyticus & Amilase & Selulase & Protease \\
\hline SL 3 SP 3.1 & - & - & + & Static & - & - & - \\
SL 3 SP 3.2 & - & - & - & - & - & - & - \\
SL 3 SP 3.3 & + & bactericidal & + & bactericidal & + & bacteriostatic & + \\
\hline
\end{tabular}

Tabel 3. Identification of potential fungal isolated from Monanchora sp. based on BLAST analysis using the ITS region

\begin{tabular}{cccccccc}
\hline Sponge & Isolate & $\begin{array}{c}\text { Sequence } \\
\text { length (bp) }\end{array}$ & Acc. no. & $\begin{array}{c}\text { Next relative by GenBank } \\
\text { alignment (AN, an organism) }\end{array}$ & $\begin{array}{c}\text { Similarity } \\
(\%)\end{array}$ & Family \\
\hline Monanchora sp. & SL 3 SP 3.3 & 638 & MW555831 & KM246746, Trichoderma reesei RHa & $99.69 \%$ & Hypocreaceae \\
\hline
\end{tabular}
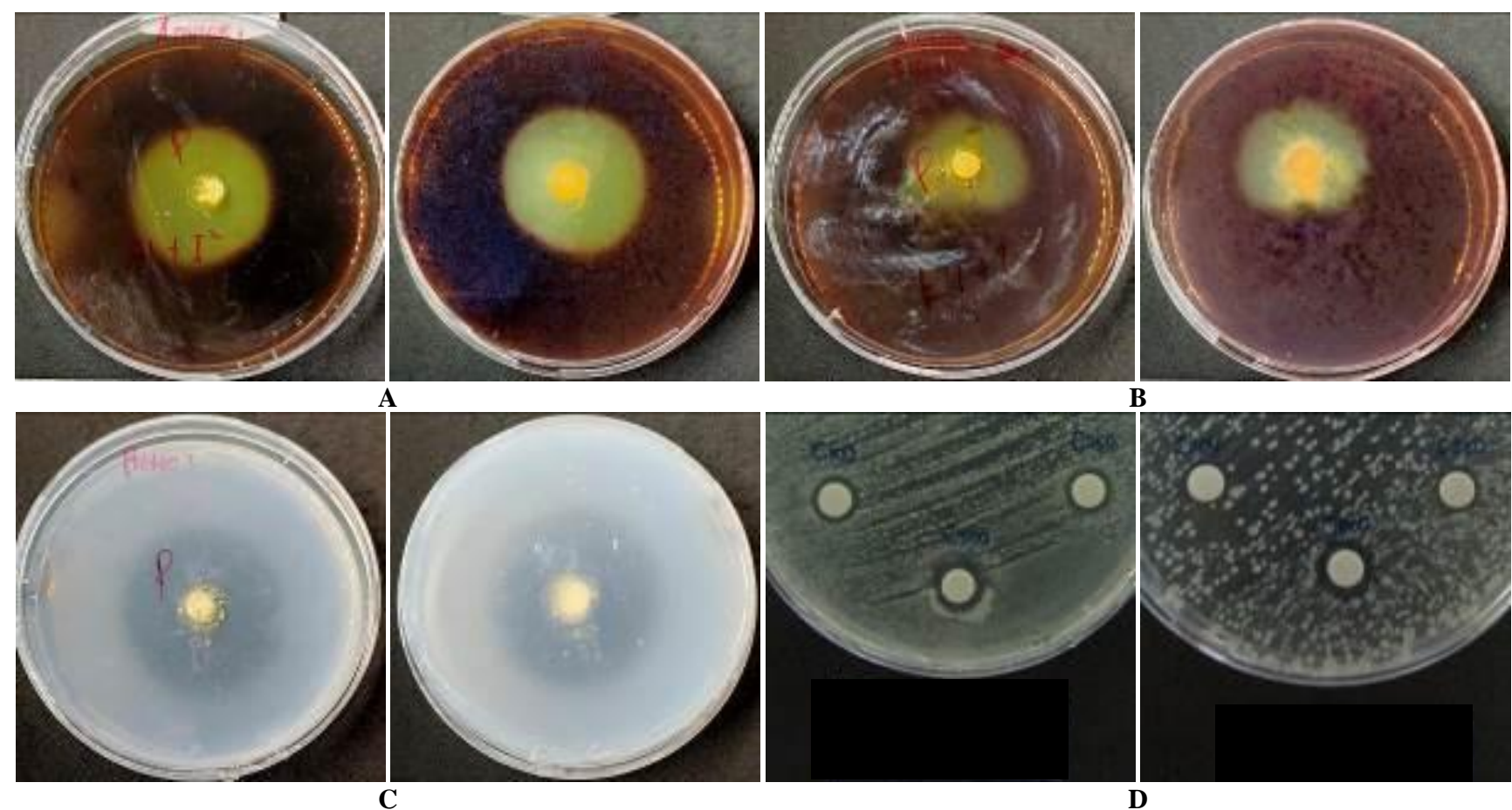

Figure 4. Screening of enzymatic activity of SL3 SP 3.3 isolate: A. Amilase, B. Selulase, C. Protease, and D. Anti-vibrio Please indicate in Figure 4.D with an arrow which one is bacteriostatic and which one is bactericidal 


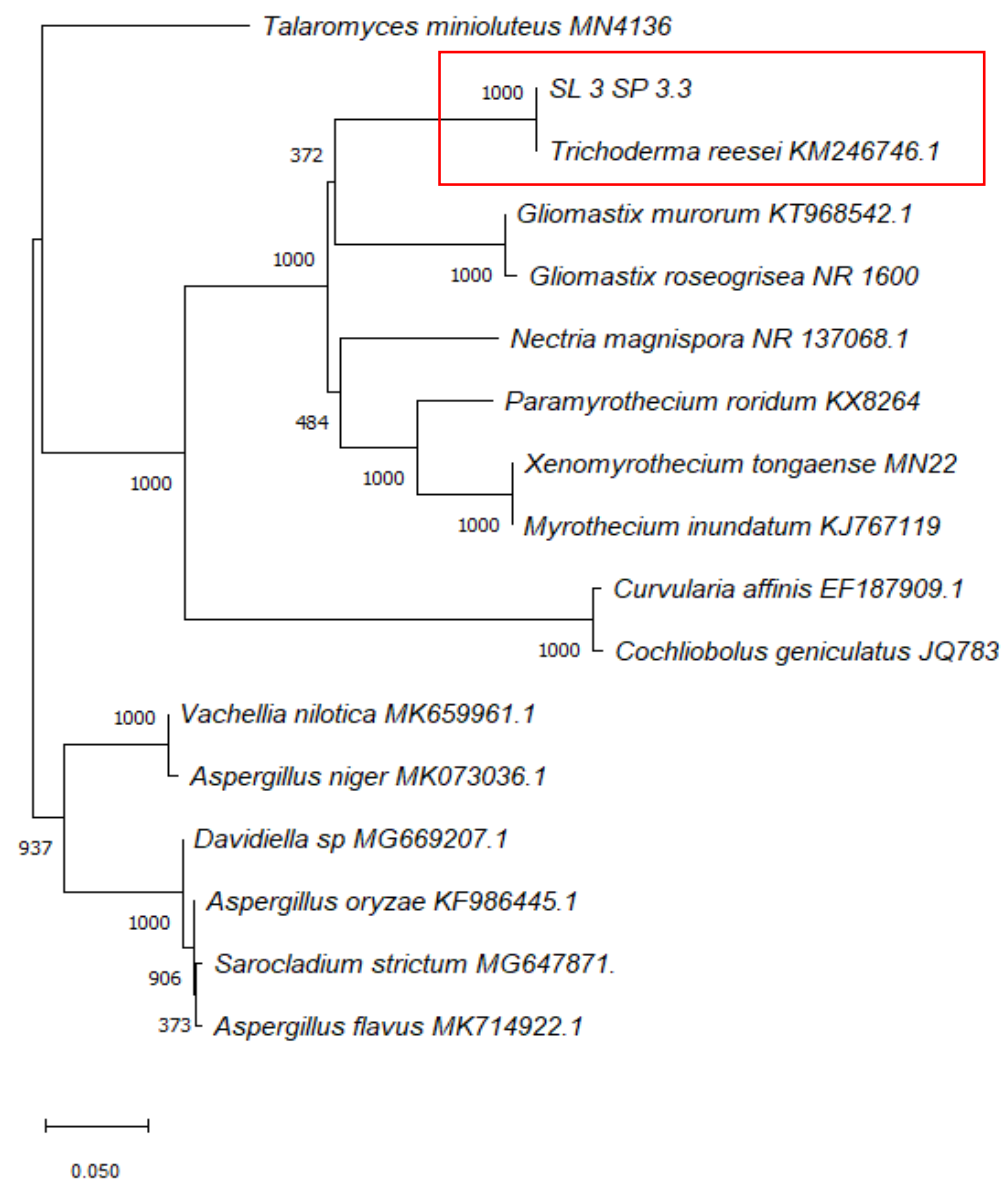

Figure 6. Phylogenetic tree of Monanchora sp. The potential fungus SL-3 SP3.3 is indicated by the red square

Enzymes produced by $T$. reesei play an important role in the synthesis of antibiotics through the mechanism of myco-parasitism in bacteria and antibiosis against bacteria. Exocellular enzymes such as cellulolytic, hemicellulolytic, pectolytic, and proteolytic enzymes can damage the main polymer component that makes up the microbial cell walls so that they can function as biocontrols against pathogens. The study results showed that the SL3 SP3.3 extract was able to inhibit the growth of 3 Vibrio species that are Gram-negative bacteria. The anti-vibrio activity of SL3 SP3.3 due to $T$. reesei to release exocellular enzymes to attack the vibrio bacterial cell walls in the form of lipopolysaccharides peptidoglycans which are polysaccharides and also proteins that can be hydrolyzed by cellulase and protease enzymes. Sorbicillinoid compound is an example of a secondary metabolite produced by the sponge-derived fungus $T$. reesei $(\mathrm{HN}-$ 2016-018) with potent antibacterial activity, especially against Gram-negative bacteria (Rehman et al. 2020). In the future, $T$. reesei has the potential to be applied in marine culture as a biocontrol agent against pathogenic diseases. A study by Assem et al. (2014) showed that fungi T. reesei-degraded date pits (FDDP) have the potential to reduce the density of bacterial population in the intestines of Oreochromis niloticus fish without impacting the fish weight or health welfare condition. A previous study by Liu et al. (2016) reported that the Trichoderma population plays a role in suppressing the disease caused by Saprolegnia in aquaculture.

Tabel 4. Diameter of inhibition zone of Trichoderma reesei SL 3 SP 3.3 extract against three Vibrio species

\begin{tabular}{ccccc}
\hline \multirow{2}{*}{ Isolate code } & \multirow{2}{*}{ Concentration $(\boldsymbol{\mu g} /$ disk) } & \multicolumn{3}{c}{ Inhibition zone $(\mathbf{m m})$} \\
\cline { 3 - 5 } & 500 & $\boldsymbol{V}$. harveyi & $\boldsymbol{V}$. parahaemolyticus & $\boldsymbol{V}$. vulnificus \\
\hline SL.3-SP.03.3 & 250 & $4.82 \pm 0.37^{*}$ & $3.83 \pm 0.2^{*}$ & $4.14 \pm 0.32^{*}$ \\
& 100 & $3.47 \pm 0.18^{*}$ & $1.67 \pm 0.15$ & $1.57 \pm 0.1$ \\
& - & $2.32 \pm 0.06^{*}$ & $1.51 \pm 0.15$ & $1.1 \pm 0.02$ \\
& + & - & - & - \\
& & $19.50 \pm 1.66^{*}$ & $15.76 \pm 1.48^{*}$ & $17.45 \pm 1.23$ \\
\hline
\end{tabular}


Tabel 5. Enzymatic Index (EI) of Trichoderma reesei isolate SL 3 SP 3.3

\begin{tabular}{|c|c|c|c|c|c|c|c|c|c|c|c|c|c|}
\hline \multirow{2}{*}{ Enzymatic activity } & \multicolumn{4}{|c|}{ Diameter of colony (mm) } & \multicolumn{4}{|c|}{ Diameter of clear zone $(\mathrm{mm})$} & \multicolumn{5}{|c|}{ Enzymatic Index (EI) } \\
\hline & R1 & $\mathbf{R 2}$ & $\mathbf{R 3}$ & $\mathbf{A}$ & R1 & $\mathbf{R 2}$ & $\mathbf{R 3}$ & $\mathbf{A}$ & R1 & $\mathbf{R 2}$ & $\mathbf{R 3}$ & $\mathbf{A}$ & stdev \\
\hline Amylase & 10.28 & 9.31 & 9.76 & 9.78 & 38.82 & 36.79 & 40.11 & 38.57 & 3.78 & 3.95 & 4.11 & 3.95 & 0.17 \\
\hline Selulase & 9.41 & 8.26 & 8.04 & 8.57 & 32.80 & 29.76 & 33.43 & 31.99 & 3.48 & 3.60 & 4.16 & 3.75 & 0.36 \\
\hline Protease & 8.44 & 9.42 & 8.78 & 8.88 & 46.71 & 47.43 & 48.94 & 47.69 & 5.53 & 5.04 & 5.57 & 5.38 & 0.30 \\
\hline
\end{tabular}

Note: R1: first repetition, R2: second repetition, R3: thirth repetition, A: Average, Stdev: Standard Deviation

Enzymatic index (EI) is the semi-quantitative approach to measure enzyme activities. The results showed that $T$. reesei has higher protease activity than other enzyme activity. The enzymatic index of protease was EI of $5.38 \pm$ 0.30 . The mechanism of the proteolytic activity is due to the hydrolysis of protein bonds originating from skim milk agar (SMA) media into simpler amino acids. Dienes et al. (2007) found that proteolytic activity in the fungus $T$. reesei which was later identified as a serine protease from fungus (a trypsin-like), has similarities protease P27 enzyme from Trichoderma harzianum. The proteolytic activity of $T$. reesei was originated from protein kinase, casein kinase II and protein kinase $\mathrm{C} 10$ which were synthesized by several gene transcription factors in the form of XYR1 (xylanase regulator 1), ACE1 (activator of cellulases 1), ACE2, HAP2/3/5 (HAT associated proteins), and CRE1 (Rodriguez-Iglesias and Schmoll 2019).

Trichoderma reesei is widely known as a cellulaseproducing microbe that has been applied in various fields of biotechnology. In this research, the cellulase activity of T.reesei SL3 SP3.3 was EI of $3.75 \pm 0.36$ which is the lowest enzymatic activity compared to amylase and protease. However, the cellulase activity of T.reesei SL3 SP3.3 was higher than the cellulase-control organism $P$. ostreatus EI of $1.8 \pm 0.1$ and largest cellulase producefungi (Penicillium chrysogenum) (EI of $3.3 \pm 0.2$ ) of Coronado-Ruiz et al. (2018). There are three types of cellulase enzymes in $T$. reesei: the cellobiohydrolase group of enzymes, Endo- $\beta-1,4-\mathrm{D}^{-}$glucanases, and $\beta-\mathrm{D}^{-}$ glucosidases (Druzhinina and Kubicek 2017). At least three genes are responsible for regulating the cellulase and hemicellulase genes, namely ACE3, XYR1, and Crt1. Gene yellow pigment regulator 1 (ypr1) also has the responsibility to produce yellow pigment in $T$. reesei as shown in Figure 3.C. The genes are regulated by the finetuned cooperation between several transcriptional factors in T. reesei. (Zhang et al. 2019). For industrial applications, several optimizations are used to maximize cellulase production such as; protein induction (Daranagama et al. 2019), modification of growth substrate (Peciulyte et al. 2014), transcriptomic engineering (Pakula et al. 2016). The correlation between protease activity and cellulase activity in $T$. reesei is still unclear or even nonexistent (Rodriguez-Iglesias and Schmoll 2019).

Filamentous fungi can degrade several types of polysaccharides that are naturally abundant in nature. Starch is one of the polysaccharides are composed of glucose. Based on enzymatic assay (Tabel 5), SL 3 SP 3.3 isolate has an amylolytic activity (EI of $3.95 \pm 0.17$ ). Fungi synthesize large amounts of starch-hydrolytic enzymes, such as $\alpha$-amylase, glucoamylase, and $\alpha$-glucosidase. These enzymes play an important role in the induction of starch, dextrin, or maltose. Amylolytic cleaves the 1,4-glycosidic bonds in starch (polysaccharides) into glucose, maltose, and other oligosaccharides. The enzyme is encoded by the gene encoding-amylase (amyA/B/C) (Wang et al. 2020). Therefore, $T$. reese $i$ has the potential as a probiotic added to the aquaculture fish feed (Assem et al. 2014).

The biotechnological potential of fungi isolated from marine sponge Monanchora sp. is quite promising. Considering that one of the problems in the aquaculture system is the poor regulation of water quality which effect the remaining feed containing protein, cellulose, and starch that are not completely degraded so that the enzymatic ability of the isolate $T$. ressei SL 3 SP 3.3 has the potential to be applied in marine aquaculture. The anti-vibrio ability of $T$. reesei SL 3 SP 3.3 has the potential as a biocontrol to overcome the diseases in marine aquaculture, which are dominated by vibriosis disease due to its anti-vibrio activity. Bioremediation and probiotics are the most potential mechanisms for resolving these problems.

\section{ACKNOWLEDGEMENTS}

The authors would like to thank the Ministry of Research and Technology, Indonesia, which has supported this research through a research grant for the Higher Education Research Consortium (KRU-PT) with contract number 201-01/ UN7.6.1/PP/2020 under the supervision of Dr. Agus Trianto.

\section{REFERENCES}

Ahmed ME. 2018. Extraction and purification of protease from Aspergillus niger isolation. Pharm Pharmacol Intl J 6: 96-99. DOI: 10.15406/ppij.2018.06.00162.

Alvarez-Navarrete M, Reyna López GE, Flores-García A, López Gómez R, Martínez-Pacheco MM. 2015. Selection and molecular identification of fungal isolates that produce xylanolytic enzymes. Genet Mol Res 14: 8100-8116. DOI: 10.4238/2015.July.17.19.

Arevabini C, Crivelenti YD, De Abreu MH, Bitencourt TA, Santos MFC, Berlinck RGS, Hajdu E, Beleboni RO, Fachin AL, Marins M. 2014. Antifungal activity of metabolites from the marine sponges Amphimedon sp. and Monanchora arbuscula against Aspergillus flavus strains isolated from peanuts (Arachis hypogaea). Nat Prod Commun 9: 33-36. DOI: 10.1177/1934578x1400900111.

Assem H, Khalifa A, ELSalhia M. 2014. Physiological and microbiological indices as indicators of evaluating dietary fungi degraded date pits as a probiotic for cultured Nile tilapia Oreochromis niloticus fingerling and its effect on fish welfare. Egypt J Aquat Res 40: 435-441. DOI: 10.1016/j.ejar.2014.10.004 
Bahry MS, Pringgenies D, Trianto A. 2017. Molecular identification of marine symbiont bacteria of Gastropods from the waters of the Krakal Coast Yogyakarta and its potential as a Multi-drug Resistant (MDR) Antibacterial Agent. AIP Conf Proc 1803: 020019. DOI: 10.1063/1.4973146.

Calcinai B, Bastari A, Bavestrello G, Bertolino M, Horcajadas SB, Pansin M, Makapedua DM, Cerrano C. 2017. Demosponge diversity from North Sulawesi, with the description of six new species. ZooKeys 2017: 105-150. DOI: 10.3897/zookeys.680.12135.

Carpa R, Cândea A, Remizovschi A, Barbu-Tudoran L, Maior MC. 2018. Cellulase production and morphology of Trichoderma reesei in different experimental conditions. Studia Universitatis Babeş-Bolyai Biologia 63: 115-129. DOI: 10.24193/subbbiol.2018.2.09.

Colonia BSO, Junior AFC. 2014. Screening and detection of extracellular cellulases (endo- and exo-glucanases) secreted by filamentous fung isolated from soils using rapid tests with chromogenic dyes. Afr J Biotechnol 13: 4694-4701. DOI: 10.5897/AJB2014.14221.

Coronado-Ruiz C, Avendaño R, Escudero-Leyva E, Conejo-Barboza G, Chaverri P, Chavarría M. 2018. Two new cellulolytic fungal species isolated from a 19th-century art collection. Sci Rep 8: 1-9. DOI: 10.1038/s41598-018-24934-7.

Cristianawati O, Sabdaningsih A, Becking LE, Khoeri MM, Nuryadi H, Sabdono A, Trianto A, Radjasa OK. 2019. Biological activity of sponge-associated fungi from Karimunjawa islands, Indonesia against pathogenic streptococcus pneumoniae. Biodiversitas 20: 2143-2150. DOI: 10.13057/biodiv/d200807.

Daranagama ND, Shioya K, Yuki M, Sato H, Ohtaki Y, Suzuki Y, Shida Y, Ogasawara W. 2019. Proteolytic analysis of Trichoderma reesei in celluase-inducing condition reveals a role for trichodermapepsin (TrAsP) in cellulase production. J Ind Microbiol Biotechnol 46: 831842. DOI: $10.1007 / \mathrm{s} 10295-019-02155-9$.

de Voogd NJ, Cleary DFR, Hoeksema BW, Noor A, Van Soest RWM 2006. Sponge beta diversity in the Spermonde Archipelago, SW Sulawesi, Indonesia. Mar Ecol Prog Ser 309: 131-142. DOI: 10.3354/meps309131.

de Voogd NJ, Francis D, Cleary R. 2008. Indo-pacific agelas view project Novel cytotoxic marine natural products View project. Mar Ecol 29: 205-215. DOI: 10.1111/j.1439-0485.2008.00238.x.

Dermawan AM, Julianti E, Putra MY, Karim F. 2019. Identification and Evaluation of Antibacterial Compounds from the Vibrio sp. associated with the Ascidian Pycnoclavella diminuta. Pharm Sci Res 6: 142-148.

Dienes D, Börjesson J, Hägglund P, Tjerneld F, Lidén G, Réczey K, Stålbrand H. 2007. Identification of a trypsin-like serine protease from Trichoderma reesei QM9414. Enzyme Microb Technol 40 1087-1094. DOI: 10.1016/j.enzmictec.2006.08.013.

Druzhinina IS, Kubicek CP. 2017. Genetic engineering of Trichoderma reesei cellulases and their production. Microb Biotechnol 10: 14851499. DOI: $10.1111 / 1751-7915.12726$

Dyshlovoy SA, Tabakmakher KM, Hauschild J, Shchekaleva RK, Otte K Guzii AG, Makarieva TN, Kudryashova EK, Fedorov SN, Shubina LK, Bokemeyer C, Honecker F, Stonik VA, Von Amsberg G. 2016. Guanidine alkaloids from the marine sponge Monanchora pulchra show cytotoxic properties and prevent EGF-induced neoplastic transformation in vitro. Mar Drugs 14: 1-17. DOI 10.3390/md14070133.

El-Demerdash A, Moriou C, Martin M-T, Rodrigues-stien ADS, Petek S, Demoy-schneider M, Hall K, Hooper JNA, Al-mourabit A. 2016. Cytotoxic guanidine alkaloids from a French Polynesian Monanchora n. sp. Sponge. J Nat Prod 79: 1929-1937. DOI 10.1021/acs.jnatprod.6b00168.

Etikan I, Musa SA, Alkassim RS. 2016. Comparison of convenience sampling and purposive sampling. Am J Theor Appl Stat 5: 1-4. DOI: 10.11648/j.ajtas.20160501.11.

FAO. 2018. The State of World Fisheries and Aquaculture- Meeting the sustainable development goals. Food and Agriculture Organization of the United Nations, Rome.

Gloeckner V, Wehrl M, Moitinho-Silva L, Gernert C, Hentschel U, Schupp P, Pawlik JR, Lindquist NL, Erpenbeck D, Wörheide G, Wörheide G. 2014. The HMA-LMA dichotomy revisited: An electron microscopical survey of 56 sponge species. Biol Bull 227: 78-88. DOI: $10.1086 /$ BBLv227n1p78.

Gogineni V, Oh J, Waters AL, Kelly M, Stone R, Hamann MT. 2020 Monanchocidin a from subarctic sponges of the Genus Monanchora and their promising selectivity against melanoma in vitro. Front Mar Sci 7: 1-11. DOI: 10.3389/fmars.2020.00058.
Hadi TA. 2011. Keragaman jenis spons pada ekosistem terumbu karang di gugus Pulau Pari, Kepulauan Seribu. Oseanologi dan Limnologi di Indonesia 37: 383-396. [Indonesian]

Handayani D, Ornando R, Rustini. 2016. Antimicrobial activity screening of symbiotic fungi from marine sponge Petrosia nigrans collected from south coast of West Sumatera, Indonesia. Intl J Pharmacognosy Phytochem Res 8:623-626.

Hooper JNA, Van Soest RWM. 2002. Systema Porifera: A Guide to the Classification of Sponges. Kluwer Academic/Plenum Publishers, New York.

Hua HM, Peng J, Dunbar DC, Schinazi RF, de Castro Andrews AG, Cuevas C, Garcia-Fernandez LF, Kelly M, Hamann MT. 2007. Batzelladine alkaloids from the caribbean sponge Monanchora unguifera and the significant activities against HIV-1 and AIDS opportunistic infectious pathogens. Tetrahedron 63: 11179-11188. DOI: 10.1016/j.tet.2007.08.005.

Indraningrat AAG, Smidt H, Sipkema D. 2016. Bioprospecting spongeassociated microbes for antimicrobial compounds. Mar Drugs 14: 166. DOI: $10.3390 / \mathrm{md} 14050087$.

Kaewkrajay C, Putchakarn S, Limtong S. 2021. Cultivable yeasts associated with marine sponges in the Gulf of Thailand, South China Sea. Intl J Gen Mol Microbiol 114: 253-274. DOI: 10.1007/s10482021-01518-6.

Kamath P, Subrahmanyam VM, Rao J, Raj P. 2010. Optimization of cultural conditions for protease production by a fungal species. Indian J Pharm Sci 72: 161-166. DOI: 10.4103/0250-474X.65017.

Khokhar I, Haider MS, Mushtaq S, Mukhtar I. 2012. Isolation and screening of highly cellulolytic filamentous fungi. J Appl Sci Environ Manag 16:223-226.

Kiran GS, Sekar S, Ramasamy P, Thinesh T, Hassan S, Lipton AN, Ninawe AS, Selvin J. 2018. Marine sponge microbial association: Towards disclosing unique symbiotic interactions. Mar Environ Res 140: 169-179. DOI: 10.1016/j.marenvres.2018.04.017.

Kumar S, Stecher G, Tamura K. 2016. MEGA7: Molecular evolutionary genetics analysis version 7.0 for bigger datasets. Mol Biol Evol 33: 1870-1874. DOI: 10.1093/molbev/msw054.

Kurniawan LA, Arief M, Manan A, Nindarwi DD. 2019. The effect of different probiotics in feed to protein retention and fat retention of Vaname Shrimp (Litopenaeus vannamei). J Aquac Fish Health 6: 32. DOI: $10.20473 /$ jafh.v6i1.11272.

Kusumaningrum HP, Zainuri M. 2015. Detection of bacteria and fungi associated with penaeus monodon postlarvae mortality. Pro Environ Sci 23: 329-337. DOI: 10.1016/j.proenv.2015.01.048.

Liu Y, Zachow C, Raaijmakers JM, De Bruijn I. 2016. Elucidating the diversity of aquatic microdochium and trichoderma species and their activity against the fish pathogen Saprolegnia diclina. Intl J Mol Sci 17: 1-15. DOI: 10.3390/ijms17010140.

Lübeck M, Lübeck PS. 2018. Isolation and screening of cellulolytic filamentous fungi. J App Sci Environ Manag 15: 203-206. DOI: 10.1007/978-1-4939-7877-9_3.

Lusi S, Sari A, Setyaningsih R, Fitriatul N, Wibowo A. 2017. Isolation and screening of cellulolytic fungi from Salacca zalacca leaf litter. Biodiversitas 18: 1282-1288. DOI: 10.13057/biodiv/d180355.

Maitig AMA, Alhoot MAM, Tiwari K. 2018. Isolation and screening of extracellular protease enzyme from fungal isolates of soil. J Pure Appl Microbiol 12: 2059-2067. DOI: 10.22207/JPAM.12.4.42.

Muller EM, Raymundo LJ, Willis BL, Haapkylä J, Yusuf S, Wilson JR, Harvell DC. 2014. Coral Health and Disease in the Spermonde Archipelago and Wakatobi. Sulawesi Coral Health and Disease in the Spermonde Archipelago and Wakatobi, Sulawesi.

Ogbonna CN, Okpokwu NM, Okafor CU, Onyia CE. 2014. Isolation and screening of amylase producing fungi obtained from garri processing site. Intl J Biotechnol Food Sci 2: 88-93.

Olmos J, Ochoa L, Paniagua-Michel J, Contreras R. 2011. Functional feed assessment on Litopenaeus vannamei using $100 \%$ fish meal replacement by soybean meal, high levels of complex carbohydrates and Bacillus probiotic strains. Mar Drugs 9: 1119-1132. DOI: 10.3390/md9061119.

Pakula TM, Nygren H, Barth D, Heinonen M, Castillo S, Penttilä M, Arvas M. 2016. Genome wide analysis of protein production load in Trichoderma reesei. Biotechnol Biofuels 9: 1-26. DOI: 10.1186/s13068-016-0547-5.

Panno L, Bruno M, Voyron S, Anastasi A, Gnavi G, Miserere L, Varese GC. 2013. Diversity, ecological role and potential biotechnological applications of marine fungi associated to the seagrass Posidonia 


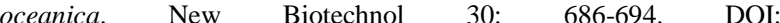
10.1016/j.nbt.2013.01.010.

Peciulyte A, Anasontzis GE, Karlström K, Larsson PT, Olsson L. 2014 Morphology and enzyme production of Trichoderma reesei Rut C-30 are affected by the physical and structural characteristics of cellulosic substrates. Fungal Genet Biol 72: 64-72. DOI 10.1016/j.fgb.2014.07.011.

Proksch P, Ebel R, Edrada RA, Wray V, Steube K. 2003. Bioactive natural products from marine invertebrates and associated fungi. Mar Mol Biotechnol 37: 117-142. DOI: 10.1007/978-3-642-55519-0_5.

Rachmawati D, Hutabarat J, Dewi EN, Windarto S. 2020 Supplementation of papain in feed on growth performance, efficiency of feed utilization, and survival rate of whiteleg shrimp (Litopenaeus vannamei). J Mar Res 9: 215-222.

Radjasa OK, Kencana DS, Sabdono A, Hutagalung RA, Lestari ES. 2009 Antibacterial activity of marine bacteria associated with sponge Aaptos sp. against Multi Drugs Resistant (MDR) strains. Jurna Matematika dan Sains 12: 147-152.

Radjasa OK, Vaske YM, Navarro G, Vervoort HC, Tenney K, Linington RG, Crews P. 2011. Highlights of marine invertebrate-derived biosynthetic products: Their biomedical potential and possible production by microbial associants. Bioorg Med Chem 19: 66586674. DOI: 10.1016/j.bmc.2011.07.017.

Rehman SU, Yang LJ, Zhang YH, Wu JS, Shi T, Haider W, Shao CL, Wang CY. 2020. Sorbicillinoid derivatives from sponge-derived fungus Trichoderma reesei (HN-2016-018). Front Microbiol 11: 1-10. DOI: $10.3389 /$ fmicb.2020.01334

Rengasamy S, Thangaprakasam U. 2018. Isolation, screening and determination of A-amylase activity from marine Streptomyces species. Intl J Pharm Pharm Sci 10: 122. DOI: 10.22159/ijpps.2018v10i4.24447.

Rodriguez-Iglesias A, Schmoll M. 2019. Protein phosphatases regulate growth, development, cellulases and secondary metabolism in Trichoderma reesei. Sci Rep 9: 1-17. DOI: 10.1038/s41598-01947421-z.

Sabdaningsih A, Cristianawati O, Sibero MT, Aini M, Radjasa OK, Sabdono A, Trianto A. 2019. Anti MDR Acinetobacter baumannii of the sponges-associated fungi from Karimunjawa National Park. AACL Bioflux 12: 1970-1983

Sabdaningsih A, Cristianawati O, Sibero MT, Nuryadi H, Radjasa OK, Sabdono A, Trianto A. 2017. Screening antibacterial agent from crude extract of marine-derived fungi associated with soft corals agains MDR-Staphylococcus haemolyticus. IOP Conf Ser: Earth Environ Sci 55: 012026. DOI: 10.1088/1755-1315/55/1/012026.

Santos MFC, Harper PM, Williams DE, Mesquita JT, Pinto ÉG, Da Costa-Silva TA, Hajdu E, Ferreira AG, Santos RA, Murphy PJ, Andersen RJ, Tempone AG, Berlinck RGS. 2015. Anti-parasitic Guanidine and Pyrimidine alkaloids from the marine sponge Monanchora arbuscula. J Nat Prod 78: 1101-1112. DOI: 10.1021/acs.jnatprod.5b00070.

Sedjati S, Ambariyanto A, Trianto A, Supriyantini E, Ridlo A, Bahry MS Wismayanti G, Radjasa OK, Mccauley E. 2020. Antibacterial activities of the extracts of sponge-associated fungus Trichoderma longibrachiatum against pathogenic bacteria. Squalen Bull Mar Fish Postharvest Biotechnol 15: 81-90. DOI: 10.15578/squalen.v15i2.438.

Sharma AK, Sharma V, Saxena J, Yadav B, Alam A, Prakash A. 2015. Isolation and screening of extracellular protease enzyme from bacterial and fungal isolates of soil. Intl J Sci Res Environ Sci 3: 334340. DOI: 10.12983/ijsres-2015-p0334-0340.

Sibero MT, Herdikiawan D, Radjasa OK, Sabdono A, Trianto A, Triningsih DW. 2018. Antibacterial activity of sponge associated fungi against vibriosis agents in shrimp and its toxicity to Litopenaeus vannamei. AACL Bioflux 11: 10-18.

Silva F, Lourenço O, Queiroz JA, Domingues FC. 2011. Bacteriostatic versus bactericidal activity of ciprofloxacin in Escherichia coli assessed by flow cytometry using a novel far-red dye. J Antibiot 64: 321-325. DOI: 10.1038/ja.2011.5.

Suryanarayanan TS. 2012. The diversity and importance of fungi associated with marine sponges. Botanica Marina 55: 553-564. DOI: 10.1515/bot-2011-0086

Toju H, Tanabe AS, Yamamoto S, Sato H. 2012. High-coverage ITS primers for the DNA-based identification of ascomycetes and basidiomycetes in environmental samples. PLoS ONE 7: e40863. DOI: 10.1371/journal.pone. 0040863 .

Trianto A, Radjasa OK, Purnaweni H, Bahry MS, Djamaludin R, Tjoa A, Singleton IAN, Diele K, Evan D. 2021. Potential of fungi isolated from a mangrove ecosystem in Northern Sulawesi, Indonesia: Protease, cellulase and anti-microbial capabilities. Biodiversitas 22: 1717-1724. DOI: 10.13057/biodiv/d220415.

Trianto A, Radjasa OK, Sibero MT, Sabdono A, Haryati D, Zilullah WOM, Syanindyta AR, Bahry MS, Armono HD, Supriadi S, Igarashi Y. 2020. The effect of culture media on the number and bioactivity of marine invertebrates associated fungi. Biodiversitas 21: 407-412. DOI: $10.13057 /$ biodiv/d210147.

van Soest RWM, Boury-Esnault N, Vacelet J, Dohrmann M, Erpenbeck D, de Voogd NJ, Santodomingo N, Vanhoorne B, Kelly M, Hooper JNA. 2012. Global diversity of sponges (Porifera). PLoS ONE 7: 123. DOI: 10.1371 /journal.pone.0035105.

van Soest RWM, Braekman J-C, Faulkner DJ, Hajdu E, Harper MK, Vacelet J. 1996. The genus Batzella: A chemosystematic problem. Bulletin de l'Institut Royal des Sciences Naturelles de Belgique Biologie 66: 89-101.

Wang BT, Hu S, Yu XY, Jin L, Zhu YJ, Jin FJ. 2020. Studies of cellulose and starch utilization and the regulatory mechanisms of related enzymes in fungi. Polymers 12: 1-17. DOI: 10.3390/polym12030530.

Wang W, Mun B, Lee Y, Reddy MV, Park Y, Lee J, Kim H, Hahn D, Chin J, Ekins M, Nam SJ, Kang H. 2013. Bioactive sesterterpenoids from a Korean sponge Monanchora sp. J Nat Prod 76: 170-177. DOI: $10.1021 / \mathrm{np} 300573 \mathrm{~m}$.

Wati LA. 2018. Analyzing the development of Indonesia shrimp industry. IOP Conf Ser: Earth and Environ Sci 137: 012101. DOI: 10.1088/1755-1315/137/1/012101.

Wittriansyah K, Trianto A, Widyaningsih S, Radjasa OK, Pribadi R. 2016. Screening of antibacterial MDR derived from sponge associated fungus of Riung Water, Nusa Tenggara Timur. Ilmu Kelautan 21: 197-202. DOI: 10.14710/ik.ijms.21.4.197-202.

Yan J, Shi X, Mei M, Dai H, Ye H. 2011. Amplifying and sequencing analysis the internal transcribed spacer (ITS) regions of Olpidium Viciae Kusano's ribosomal DNA in broad bean. Advanced Materials Research 271-273: 507-513. 10.4028/www.scientific.net/AMR.271-273.507.

Yusuf S, Beger M, Citra A, Tassakka MAR, Brauwer MDE, Pricella A, Umar W, Limmon GV, Moore AM, Jompa J. 2021. Cross shelf gradients of scleractinian corals in the Spermonde Islands, South Sulawesi, Indonesia. Biodiversitas 22: 1415-1423. DOI: 10.13057/biodiv/d220344.

Zhang J, Chen Y, Wu C, Liu P, Wang W, Wei D. 2019. The transcription factor ACE3 controls cellulase activities and lactose metabolism via two additional regulators in the fungus Trichoderma reesei. J Biol Chem 294: 18435-18450. DOI: 10.1074/jbc.RA119.008497 